FACTA UNIVERSITATIS

Series: Physical Education and Sport, Vol. 16, No 2, 2018, pp. 487 - 492

https://doi.org/10.22190/FUPES171103043R

Professional article

\title{
PRESCHOOL SPORT MANAGEMENT: THE ROLE OF BASIC SPORTS IN PRESCHOOLS
}

\author{
UDC 796.071.4:373.2-053.4
}

\author{
Igor Radošević ${ }^{1}$, Ana Gavrilović ${ }^{2}$, Jovan Veselinović ${ }^{3}$, Ivana Parčina ${ }^{3}$ \\ ${ }^{1}$ Faculty of Management, Belgrade Metropolitan University, Belgrade, Serbia \\ ${ }^{2}$ Faculty of Business and Law, University Union-Nikola Tesla, Belgrade, Serbia \\ ${ }^{3}$ Faculty of Management in Sport, ALFA BK University, Belgrade, Serbia
}

\begin{abstract}
Basic sports management in preschools is an area on which, in the region of Southeast Europe, no country has particularly focused. Investing in preschool sports organization is necessary for several reasons: The first reason is to raise the level of the nation's health. The second reason relates to the prevention of illness in later life, and the third reason is the possibility of creating future athletes, or making a home base from which the most talented children would be directed to local clubs in sports in which they have shown interest in or talent for. It is essential for sports activities to be available to every child, and in order to achieve this, sports for children should be free of charge.
\end{abstract}

Key words: children, basic sports, free sport, preschools, physical education teachers

\section{INTRODUCTION}

Basic sports management in preschools is an area on which, in the region of Southeast Europe, no country has particularly focused. Introducing basic sports in preschools is aimed at children's adequate physical development, and for making a base from which the most talented children will be selected and directed towards sports which they can play on the professional, amateur or recreational level (Balyi, Way, \& Higgs, 2013)

Historically speaking, preschool children had much more physical activity in the past compared to children today. There were no distracting elements, such as smartphones, tablets or computers that take away attention and most of the free time of children today. The development of new technologies has contributed to the more effective functioning of people, but at the same time it has reduced physical activity, and has thereby contributed to the declining health status of the nation, especially of children (Gallahue \& Donnelly, 2007).

Received November 3, 2017 / Accepted November 4, 2018

Corresponding author: Igor Radošević

Faculty of Management, Belgrade Metropolitan University, Tadeuša Košćuška 63, 11000 Belgrade, Serbia

Phone: +381 113283445 •E-mail igy.radosevic@gmail.com 
It should be noted that the health of a nation showed us that the lack of physical activity of people in Serbia has reduced their life expectancy by five years. Children who are not physically active are more susceptible to later deformities, such as flat feet, hyper curved spinal column (scoliotic, kyphotic and lordotic bad posture) and obesity (Purenović, 2007). Physical activity improves general health, and reduces risk of disease and progression of chronic illnesses, such as cardiovascular disease, type-2 diabetes and obesity. In relation to chronic pain conditions, appropriate parameters (frequency, duration, intensity) of physical activity can significantly reduce pain and related symptoms. In chronic pain, strict guidelines for physical activity are lacking, but frequent movement is preferable to a sedentary population (Ambrose \& Golightly, 2015). According to the World Health Organization (2016), since 1980, the number of obese people in the world doubled, so that in 2014 more than 1.9 billion adults were overweight, of which over 600 million were obese (13\% of the adult population), while 41 million children (aged up to five years) were obese or overweight. When it comes to obesity in Serbia, there are $13.9 \%$ of obese children (younger than 5 years old), that is almost double compared to the global average of 6.2\%, for the period 2005-2015 (Mitić \& Gligorijević, 2013).

A study of children's motives for sports participation throughout the United States shows that fun is the main reason, followed by the need to learn new skills, spend time with friends, and experience the thrill of competition. Winning is also stated as a motive, but it is not their main reason, as many parents mistakenly believe (Botterill \& Patrick, 2003).

Introducing children to basic sports in preschool starts from an early age, and a lot depends on the family and the environment they grow up in. In the period from 2 to 5 years of age, children start creating the need for exercise and running, and that period is considered to be crucial for explosive muscle fiber development, which is of crucial importance for their later careers as athletes or even in everyday life. At this age, children should be encouraged to take part in physical activity as much as possible, and should not be hindered in any way, most often out of fear of falling, injuries or material damage (Bačanac, Petrović, \& Manojlović, 2009).

It must be noted that many sports experts believe that in the process of creating future top athletes, school age (grades 1 to 4 of elementary school) represents the delayed period to start playing sports. For these reasons, it is necessary to cooperate with different national federations (Athletics Federation of Serbia, Gymnastics Federation of Serbia and Swimming Federation of Serbia), as representatives of basic sports, whose experts will design programs which will be used with preschool children. It is necessary to cooperate with different sports federations, so that children in preschools can have the opportunity to try out as many sports as possible.

The main aims of the current paper are to point to the connection between preschool children and basic sports, and the consequences that the lack of physical activity leave on preschool children, as well as point to the methods that need to be implemented in working with preschool children.

\section{THEORETICAL CONSIDERATIONS OF THE PROBLEM}

Basic sports in preschools aim to develop motor skills in children (4-7 years of age) by introducing children to athletics, gymnastics, and swimming. This entails physical education teacher engagement in work with children on proper running, stretching, muscle strengthening, and swimming techniques, as well as creating a team and competitive spirit along with the 
organization of competitions with their peers in athletics, gymnastics, swimming, and other sports. At the end of the preschool age, before starting primary school, children who went through the program gained basic motor skills, and therefore a significant advantage on the basis of which selection and direction to different sports (individual or team sports) is made (based on children's interest and talent). It must be noted that the primary task of basic sports is intended to help create healthy individuals, while the secondary task is to create future athletes. It is not possible for every child to be a professional athlete. It is important that all children love sports, even if they play them at an amateur or recreational level, because it will help them lead healthy lives.

In that sense, none of the activities before that should be considered sports activities, but as physical exercise, regardless of the fact that sports clubs, such as football, basketball, athletics, gymnastics, swimming, tennis clubs, and other sports clubs already have training sessions for ages four to seven. According to the Action Plan for the Implementation of the Strategy for the Development of Sports in the Republic of Serbia in the period from 2014 to 2018 (The Official Gazette 1/2015), preschool sports have been recognized and included at the same level as school and university sports. The goal of physical activity and introducing children to sports activities is the adoption of specific motor skills needed to effectively address the needs of developing and maintaining good health, using free time in a meaningful way, and solving everyday motor tasks. The purpose of quality physical activity consists of the acquisition of positive experiences when a child learns motor movements and socializes with others (Deretić, 2017).

For the implementation of basic sports in preschools, it is necessary to include trained staff (physical education teachers), purchase equipment for gymnastics (mats), and make mini running tracks with supporting props (ladders, cones, hurdles). In order to gain insight into current health and motor skill status, and in order to provide an analysis and comparison on an annual basis, it is necessary for preschool children to undergo a complete medical and motor skill examination conducted in cooperation with the Institute of Sport and Sports Medicine of the Republic of Serbia. Testing of children's motor skills should also be implemented in preschool children who do not participatea in the exercise program in order to compare the results of active and non-active children. Re-tests are necessary in order to compare the initial and the final results. The realization of the swimming program should be implemented depending on the availability of the pools around preschools. Programs should be implemented depending on the weather conditions: Athletics should be carried out in the autumn-spring period in the preschool yard, gymnastics should be carried out in the winter time indoors (at the gyms), while swimming should be carried out in the summer. The implementation of basic sports in preschools should be carried out in three phases:

- Phase 1: Program implementation in Belgrade, where in partnership with 17 municipalities it would be carried out in preschools around the city. Participation of the municipal sports secretariats, which would receive instructions on how to implement the program is planned, while during the program implementation graduate students from the Faculty of Sport and Physical Education would be involved, and in the context of professional practice would gain experience in working with children;

- Phase 2: Project implementation in other cities in Serbia in cooperation with the city and municipal sports secretariats (Novi Sad, Niš, Kragujevac, Subotica, Čačak, Užice, Kraljevo, Novi Pazar, Vranje, Leskovac), thereby engaging local staff who have a proper sports education; 
- Phase 3: Proposing the program "Preschool Sports Management - The Role of Basic Sports in Preschools" as regular activities for public preschools in the Republic of Serbia.

In order to motivate children to love sports, it is necessary to focus their attention by using the right methods. Among young people, fun and friendship are the most important reasons for playing sports. When someone decides the time is right to focus a child towards sports, he should consider motivational readiness of the child, cognitive readiness of the child and the potentially harmful effects of sports.

According to Bačanac, Radović, \& Vesković (2007), young athletes selected 8 motives due to which they primarily joined sports. Research shows that social needs (need for companionship and friendship, internal need for play and fun contained in the phrase "love of sport", and improving and maintaining good health) are the most frequently mentioned reasons for their commitment to sports.

Table 1 Motives for playing sports (in Bačanac et al., 2007)

\begin{tabular}{|c|c|}
\hline \multicolumn{2}{|c|}{ Motives for playing sports } \\
\hline $\begin{array}{l}10 \text { Reasons for children in the US } \\
\text { (Scholde \& McGuire, 2007) }\end{array}$ & $\begin{array}{l}10 \text { Reasons for children in Serbia } \\
\text { (Bačanac et al., 2007) }\end{array}$ \\
\hline 1. Fun & 1. Friendship \\
\hline 2. Improving skills & 2. The love of sport \\
\hline 3. Be fit & 3. Health \\
\hline 4. Do something you're good at & 4. Fun \\
\hline 5. The thrill of competition & 5. Travel \\
\hline 6. Exercise & 6. Nice look \\
\hline 7. Being part of a team and play for the team & 7. Personal affirmation - success \\
\hline 8. Challenge competition & 8. Popularity \\
\hline 9. Learning new skills & 9. Money \\
\hline 10. Victory & 10. Parental wishes \\
\hline
\end{tabular}

The authors of this paper, in cooperation with the Preschool Sport Development Association, conducted a study of mobility, motor abilities, and motivation for physical exercise on a sample of 100 preschool children (7-year-olds) in the preschool institution Lipa (the Municipality of Stari Grad, 19 Solunska St., Belgrade), and the preschool called Lunja (the Municipality of Vračar, 42 Janka Lisjaka St., Belgrade), as part of the physical education in preschools program that lasted for 54 days. It should be noted that in the research part that included testing, only athletics exercises were applied, while there were no adequate conditions for performing gymnastics and swimming exercises. During the program, children were tested in performing basic exercises, such as double-leg jumps over obstacles, squats, jumps over cones, running with a change of direction around the cones, duck walk, jumps across the ladder, and standing on one leg. The results at the initial measurement identified poor motor skills $(69 \%)$, incorrect walking $(27 \%)$, running $(47 \%)$ and jumping techniques (71\%), as well as difficulty in performing basic warm-up exercises $(36 \%)$. At the end of the research, the authors concluded that the implementation of the program, which was performed twice a week by doing basic athletics exercises, such as double-leg jumps over obstacles, jumps over the cones, running with a change of direction around the cones, duck walk, jumps over the ladder, and standing on one leg to maintain balance and stability, improved children's mobility significantly. The deficiencies in walking, 
running and jumping techniques were partially corrected, and other motor skills were improved, also. Finally, increased motivation compared to their peers who did not participate in the study was noted.

The interest of preschool children in sports was huge, with a few exceptions, while the biggest problem was the situation of non-existent staff to work with the children. Positions where the preschools were located proved to be very important during the research. Children from the preschool institution Lipa, which is located near the Danube River, surrounded by plenty of free space and green areas, showed higher levels of mobility and motor skills compared to their peers from preschool Lunja, located inside the city, surrounded by dense streets and tall concrete buildings, with a significantly smaller free spaces and parks where children can freely run and play sports. Motivation of children was on a high level, with a huge desire to compete and prove themselves. There were also individuals whose motivation was variable, taking into account the uncertainty of performing a practical exercise, as well as risking mockery by their peers. Each child who had a problem with motivation required a special approach, while six children showed complete disinterest in any physical activity.

Hence, children cannot be forced to play sports against their will because it will create the opposite effect. Fun is the best way for children to start to like sports, i.e., physical activity, while the organization of children's competitions is the best method to select and direct each child to the sport s/he has shown talent and interest for. Children are not aware that playing sports at a later age will help them form as individuals, and lead healthy and productive lives as a way to prevent potential addiction (cigarettes, alcohol, drugs, and video games). Accordingly, there is an increasing number of children becoming addicted to cigarettes, alcohol, and drugs (Veerman, 2010), and video games (Yilmaz, Griffiths, \& Kan, 2017) at a younger age. Unfortunately, the current situation in preschools across Serbia shows a lack of desire, will, and conditions to work with children because preschools do not have adequate staff, i.e., physical education teachers, to deal with directing children towards sports. Teachers in preschools are not trained to work with children in sports, and their understanding of sports comes down to letting the children play in the yard by themselves, and precisely for this reason it is necessary to make a strategy for the development of preschool sports.

\section{CONCLUSION}

We can conclude that investing preschool sports organizations is necessary for two main reasons. The first reason is to raise the level of the nation's health by preventing illnesses and certain addictions in later life, and the second reason is the possibility of making a home base from which the most talented children would be directed to local clubs and becoming future athletes. It is essential for sports activities to be available to every child, and in order to achieve this, sports for children should be free of charge. The evaluation instruments proposed by this paper include fine motor precision, fine motor integration, manual dexterity, bilateral coordination, balance, running speed and agility, upper limb coordination, and strength. The crucial problems the authors envisage relate primarily to children in private preschools, where a large number of institutions do not have adequate conditions, such as a backyard where most of the performed exercises in basic sports are held. 
Hence, every preschool should have a physical education teacher, like primary and secondary schools do that will work daily with children using programes made by the athletics, gymnastics and swimming associations' experts in cooperation with certified higher education sports institutions. This will also open up the possibility for creating new jobs for graduate physical education teachers in preschools modeled on the examples of primary and secondary schools. Investing in the children's future should be a priority of any government. The money invested in children's sports activities will be returned in multiple positive ways.

\section{REFERENCES}

Ambrose, K.R., \& Golightly, Y.M. (2015). Physical exercise as non-pharmacological treatment of chronic pain: why and when. Best Practice \& Research Clinical Rheumatology, 29(1), 120-130.

Bačanac, Lj., Petrović, N., \& Manojlović, N. (2009). Priručnik za roditelje mladih sportista (Guide for parents of young athletes). Serbian Institute of Sport and Sports Medicine. In Serbian

Strategija razvoja sporta u Republici Srbiji za period 2014-18 (Strategy for the development of sport in the Republic of Serbia for the period 2014-18). The Official Gazette 1/2015, Retrived April 10, 2017 from the World Wide Web: http://www.paragraf.rs/propisi/strategija_razvoja_sporta_u_republici_srbiji_za_period_2014-2018_godine.html

Bačanac, Lj., Radović, M., \& Vesković, A. (2007). Specificities of motivational profile of young athletes of Serbia. Serbian Journal of Sports Sciences, 1 (1-4), 21-28

Balyi, I., Way, R., \& Higgs, C. (2013). Long-term athlete development. Human Kinetics.

Botterill, C., \& Patrick, T. (2003). Perspective: The key to life. Lifeskills.

Deretić, M. (2017). Sport za decu predškolskog uzrasta (Sport for preschool children). Unpublished Masters Thesis, Faculty ofSport, University Union - Nikola Tesla. In Serbian

Gallahue, D.L., \& Donnelly, F.C. (2007). Developmental physical education for all children. Human Kinetics.

Mitić, S., \& Gligorijević, M. (2016). Društveni marketing u funkciji unapređenja ishrane i zdravlja potrošača u Srbiji (Nutrition and health issues of consumers in serbia: social marketing perspective). Marketing, 47(4), 255-266. In Serbian

Purenović, T. (2007). Review of national and international research Studies in postural deformities: The period from 2000 to 2007. Facta Universitatis Series Physical Education and Sport, 5(2), 139-152.

Scholde, M., \& McGuire, R. (2007). Coaching athletes - a foundation for success. LA84 Foundation.

Veerman, P.E. (2010). The ageing of the UN Convention on the rights of the child. The International Journal of Children's Rights, 18(4), 585-618.

Y1lmaz, E., Griffiths, M.D., \& Kan, A. (2017). Development and validation of videogame addiction scale for children (VASC). International Journal of Mental Health and Addiction, 15(4), 869-882.

World Health Organization (2016). Obesity and overweight, Fact sheet, 2016. Retrived on February 5, 2017, on the World Wide Web: www.who. int/mediacentre/factsheets/fs311/en/

\section{MENADŽMENT PREDŠKOLSKOG SPORTA: ULOGA BAZIČNIH SPORTOVA U PREDŠKOLSKIM USTANOVAMA}

Osnovno upravljanje sportom u predškolskim ustanovama predstavlja oblast na koju nijedna zemlja u regionu Jugoistočne Evrope nije posebno fokusirana. Ulaganje u organizaciju predškolskog sporta neophodno je iz nekoliko razloga: Prvi razlog je podizanje nivoa zdravlja nacije. Drugi razlog se odnosi na sprečavanje oboljevanja u kasnijem životu, a treći razlog je mogućnost "stvaranja” budućih sportista ili stvaranja baze iz koje bi najtalentovanija deca bila upućivana u lokalne klubove u sportu prema kome su pokazala interes ili talenat. Neophodno je da sportske aktivnosti budu dostupne svakom detetu, a kako bi se to postiglo, sport za decu treba da bude besplatan.

Ključne reči: deca, bazični sportovi, predškolske ustanove, profesori fizičkog vaspitanja 